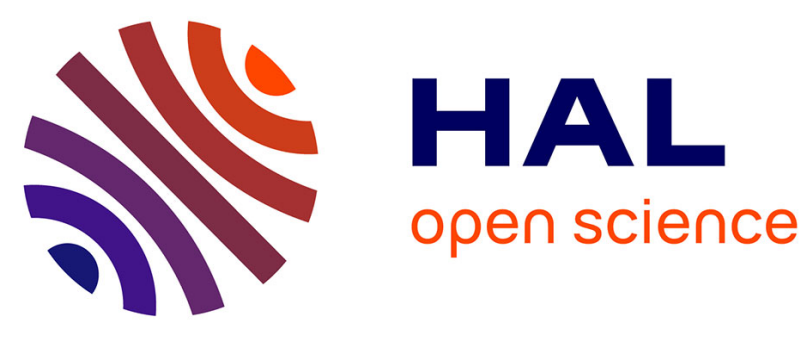

\title{
Probiotics in Dairy Fermented Products
}

Emiliane Andrade Araújo, Ana Clarissa dos Santos Pires, Maximiliano Soares

Pinto, Gwénaël Jan, Antonio Fernandes de Carvahlo

\section{To cite this version:}

Emiliane Andrade Araújo, Ana Clarissa dos Santos Pires, Maximiliano Soares Pinto, Gwénaël Jan, Antonio Fernandes de Carvahlo. Probiotics in Dairy Fermented Products. Probiotics, In Tech Open, 654 p., 2012, 978-953-51-0776-7. 10.5772/3444 . hal-01454536

\section{HAL Id: hal-01454536 https://hal.science/hal-01454536}

Submitted on 6 Jun 2020

HAL is a multi-disciplinary open access archive for the deposit and dissemination of scientific research documents, whether they are published or not. The documents may come from teaching and research institutions in France or abroad, or from public or private research centers.
L'archive ouverte pluridisciplinaire HAL, est destinée au dépôt et à la diffusion de documents scientifiques de niveau recherche, publiés ou non, émanant des établissements d'enseignement et de recherche français ou étrangers, des laboratoires publics ou privés. 


\title{
Probiotics in Dairy Fermented Products
}

\author{
Emiliane Andrade Araújo, Ana Clarissa dos Santos Pires, \\ Maximiliano Soares Pinto, Gwénaël Jan and Antônio Fernandes de Carvalho
}

Additional information is available at the end of the chapter

http://dx.doi.org/10.5772/51939

\section{Introduction}

Since ancient times, food has been considered essential and indispensable to human life. Numerous studies clearly show that an individual's quality of life is linked to daily diet and lifestyle (Moura, 2005).

Interest in the role of probiotics for human health began as early as 1908 when Metchnikoff associated the intake of fermented milk with prolonged life (Lourens-Hattingh and Vilijoen, 2001b). However, the relationship between intestinal microbiota and good health and nutrition has only recently been investigated. Therefore, it was not until the 1960's that health benefit claims began appearing on foods labels.

In recent years, there has been an increasing interest in probiotic foods, which has stimulated innovation and fueled the development of new products around the world. Probiotic bacteria have increasingly been incorporated into foods in order to improve gut health by maintaining the microbial gastrointestinal balance. The most popular probiotic foods are produced in the dairy industry because fermented dairy products have been shown to be the most efficient delivery vehicle for live probiotics to date.

In this chapter, we will discuss the application of probiotic microorganisms in fermented dairy products, particularly cheeses. In addition, we will also discuss the benefits of probiotic fermented foods on human health.

\section{Probiotic concepts}

The word "probiotic" comes from Greek and means "for life" (Fuller, 1989). Over the years, the term "probiotic" has been given several definitions. "Probiotic" is used to refer to cultures of live microorganisms which, when administered to humans or animals, improve properties of indigenous microbiota (Margoles and Garcia, 2003). In the food industry, the 
term is described as "live microbial food ingredients that are beneficial to health" (Clancy, 2003).

It is important to mention that for a microorganism to be considered probiotic, (Figure 1), it must survive passage through the stomach and maintain its viability and metabolic activity in the intestine (Hyun and Shin, 1998). Native inhabitants of the human or animal gastrointestinal tract, such as lactobacilli and bifidobacteria, are considered to be probiotic, but often display low stress tolerance, which reduces their viability in probiotic applications. Microorganisms traditionally grown in fermented foods, such as lactic acid bacteria, propionibacteria and yeasts, are also considered for these applications..

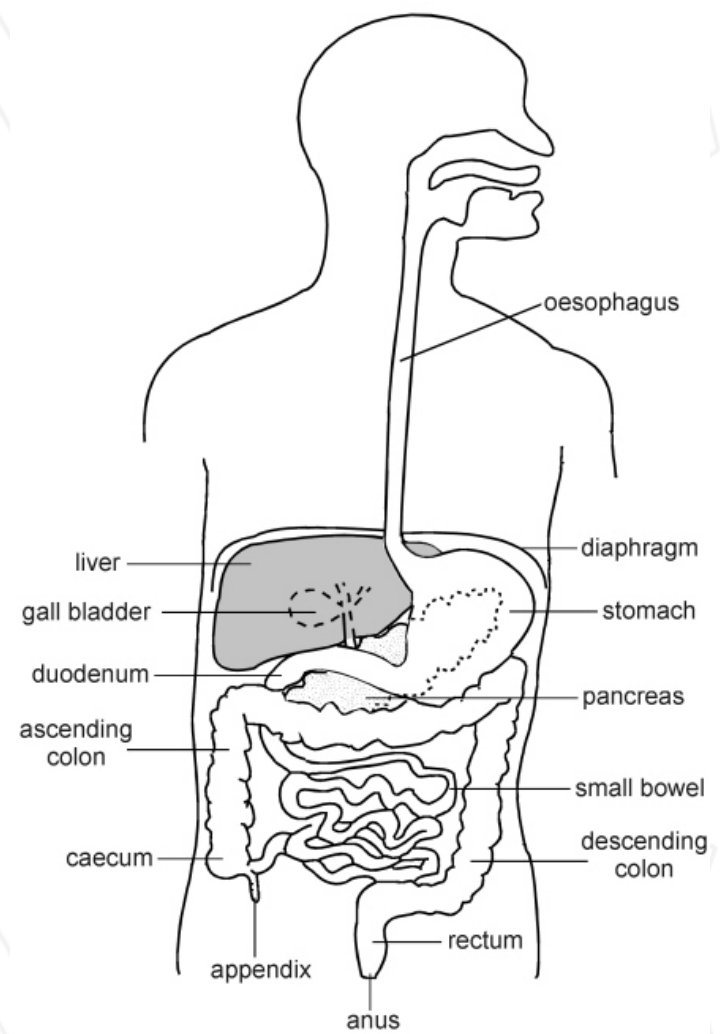

Figure 1. Schematic representation of gastrointestinal tract

It is essential that commercialized probiotic products which make health claims meet the minimum criterion of one million viable probiotic cells per milliliter of product at the expiration date. Accordingly, the minimum dosage of probiotic cells per day for any beneficial effect on the consumer is considered to be $10^{8}-10^{9}$ probiotic CFU ml-1 or CFU g-1, $^{-1}$, which corresponds to an intake of $100 \mathrm{~g}$ product containing $10^{6}-10^{7} \mathrm{CFU} \mathrm{ml}{ }^{-1}$ or CFU g-1 per day (Lorens-Hattingh and Viljoen, 2001a). 


\subsection{Selection of probiotic microorganisms}

The human intestinal tract constitutes a complex ecosystem of microorganisms. The bacterial population in the large intestine is very high and can reach maximum counts of $10^{12} \mathrm{CFU} \mathrm{g}^{-1}$. In the small intestine, the bacterial content is considerably lower at only $10^{4}-10^{8}$ CFU g-1 ${ }^{-1}$ In the stomach only $10^{1}-10^{2} \mathrm{CFU} \mathrm{g}^{-1}$ are found due to the low $\mathrm{pH}$ of the environment (Lorens-Hattingh and Viljoen, 2001b).

It is known that microbiota in the human intestine changes during human development. The intestine of newborn babies is fully sterile, however immediately after birth, colonization of many kinds of bacteria begins. On the first and second days after birth, coliforms, enterococci, clostridia and lactobacilli have been shown to be present present in infants' feces. Within three to four days, bifidobacteria begins colonization and becomes predominant around the fifth day. Simultaneously, coliform counts decrease. Breast-fed babies show 1 log-count more of bifidobacteria in feces than bottle-fed babies. Enterobacteriaceae, streptococci, and other putrefactive bacteria counts are higher in bottlefed babies, suggesting that breast-fed babies are more resistant to gastrointestinal infections than the bottle-fed infants (Lorens-Hattingh and Viljoen, 2001b).

In addition to the microbiota changes that occur during human aging, the microbiota in the gastrointestinal system can also change because of the food and health conditions of an individual. For example, use of antibiotics can damage the equilibrium of intestinal microbiota, reducing counts of bifidobacteria and lactobacilli and increasing clostridia. The ensuing imbalance can cause diarrhea in elderly and immunocompromised people.

To help improve the balance of intestinal microbiota, probiotic microorganisms can be added to the human diet in order to stimulate the growth of preferred microorganisms, crowd out potentially harmful bacteria, and reinforce the body's natural defense mechanisms.

The selection of probiotic microorganisms is based on safety, functional and technological aspects, as reported by (Saarela et al., 2000). These are summarized in Figure 2.

Certain probiotic bacteria have been extensively studied and are already on the market, as shown in Table 1.

Before probiotic strains can be delivered to consumers, they must first be able to be manufactured under industrial conditions. They must then survive and retain their functionality during storage as frozen or freeze-dried cultures, as well as in the food products into which they are finally formulated. Moreover, they must be able to be incorporated into foods without producing off-flavors or textures (Saarela et al., 2000).

Functional food requirements must take into consideration the following aspects in relation to the probiotics: The preparation should remain viable for large-scale production; it should remain stable and viable during storage and use; it should be able to survive in the intestinal ecosystem (Prado et al., 2008). 


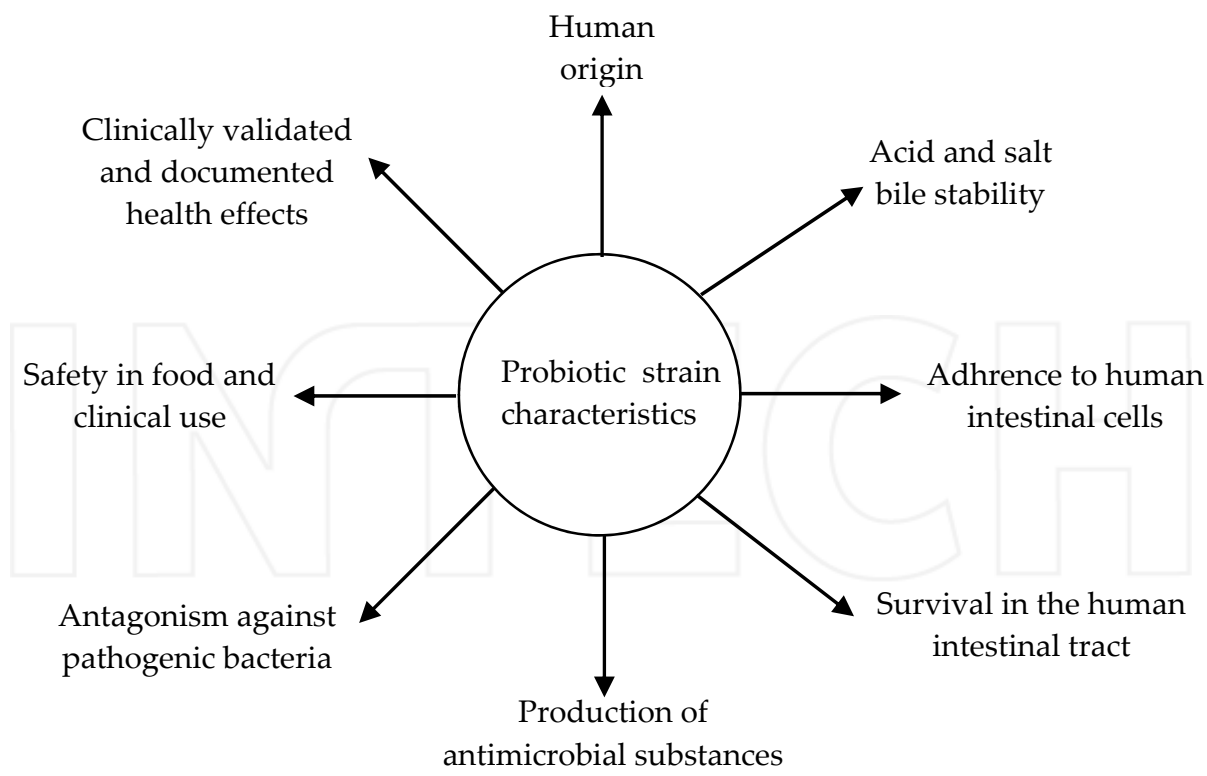

Figure 2. Theoretical basis for selection of probiotic microorganism selection (adapted from Saarela et al., 2000).

\begin{tabular}{cc}
\hline Strains & Origin \\
\hline Lactobacillus casei Shirota & Yakult, Japan \\
Lactobacillus reuteri MM53 & BioGaia, Sweden \\
Bifidobacterium lactis HN019 & Danisco, France \\
Lactobacillus rhamnosus GG & Valio, Finland \\
Lactobacillus acidophilus NCFM & Nestle, Switzerland \\
Lactobacillus casei DN-173 010 & Danone, France \\
Lactobacillus casei CRl-431 & Chr. Hansen, USA \\
Bifidobacterium animalis BB12 & Chr. Hansen, Denmark \\
Bifidobacterium animalis DN173010 & Danone, France \\
\hline
\end{tabular}

Source: Prado et al., 2008

Table 1. Probiotic bacteria marketed worldwide

\section{Beneficial effects of probiotics}

The role of balanced nutrition for health maintenance has attracted the attention of the scientific community, which in turn has produced numerous studies in order to prove the performance of certain foods in reducing the risk of Some diseases. There has also been 
considerable growing interest in encouraging research into new natural components (Thamer and Penna, 2006).

In a healthy host, a balance exists among members of the gut microbiota, such that potential pathogenic and non-pathogenic organisms can be found in apparent harmony. In the case of bacterial infection, this balance can become disturbed, leading to often dramatic changes in the composition.

For most bacterial infections, nonspecific antibiotics are used, killing both non-pathogenic members of gut microbiota as well as pathogenic members. This can lead to a substantial delay in the restoration of healthy gut microbiota (Reid et al, 2011). The restoration of the gut microbiota balance is believed to be important because maintaining a healthy and balanced gut microbiota throughout life is thought to help preserve health and favor longevity.

The most comprehensive analysis of human microbiota to date examined 27 distinct sites in the body and revealed the presence of 22 bacterial phyla, with most sequences $(92.3 \%)$ related to just four phyla: Actinobacteria (36.6\%), Firmicutes (34.3\%), Proteobacteria $(11.9 \%)$ and Bacteroidetes (9.5\%) (Costelo, 2008).

The metabolic capacity of gut bacteria is extremely diverse. This diversity is influenced by the large number of bacterial genera and species. Lactic acid species are present, as well as peptide-degrading bacteria, amino acids, and other methanogenic bacteria components of the gut microbiota which grow with the intermediate products of fermentation such as hydrogen, lactate, succinate and ethanol (Topping and Clifton, 2001).

In host's diet residue (matter undigested by its digestive system including resistant starch, fibers, proteins and peptides) substrates for primary fermentation can be found. Other important available substrates derive from mucin glycoproteins, exfoliated epithelial cells and pancreatic Secretions (MacFarlane et al., 1992).

Hydrolysis and carbohydrate metabolism in the large intestine is influenced by a variety of physical, chemical, biological and environmental parameters. Probably the nature and quantity of available substrate that has greater meaning, making the diet easier and the main mechanism by which to influence the profile of fermentation. Other factors affecting the colonization and growth of bacteria in the intestine are intestinal $\mathrm{pH}$, which inhibits the production of metabolites (acids and peroxides) and specific inhibitory substances (bacteriocins), bile salts and molecules and cells which constitute the immune system (Rastall et al., 2000) .

Knowledge of intestinal gut microbiota and their interactions led to the development of food strategies aimed at the stimulation and maintenance of normal bacteria present in the gut (Gibson and Fuller, 2000).

According to Wohlgemuth (2010), strategies for studying mechanisms of probiotic action involve in-vitro models, or conventional or gnotobiotic animal models, plus development of a simplified human intestinal gut microbiota. Wohlgemuth's article proposes certain requirements that a model should ideally fulfill: 
- Selected bacterial species should represent numerically dominant organisms of the human gut microbiota.

- By and large, the metabolic activity of this community should mimic that of normal human gut microbiota.

- The genome sequence of all members of the microbial community should be known.

- The members of this consortium should form a stable community in rodents. It should be possible to maintain this community under gnotobiotic conditions from generation to generation.

- The composition of the microbial community should be modifiable when required.

It is possible to increase the number of health-promoting microorganisms in gut microbiota through the introduction of probiotics in the diet. The probiotics will selectively modify the composition of the gut microbiota, providing the probiotic microorganisms demonstrate a competitive advantage over other bacteria in the ecosystem (Crittenden, 1999). Probiotic therapeutic properties are listed in Table 2.

\section{Probiotic therapeutic properties}

Influence on host gut microbiota and pathogenic bacteria

Improvement of specific enzymatic activities

Production of antibacterial substances

Competitive exclusion of pathogenic bacteria

Induction of defensin production

Improvement of intestinal barrier function

Modulation of host immune functions

Modulation of intestinal carcinogenesis

Modulation of cholesterol uptake

Wohlgemuth et al. (2010); Reddy and Rivenson (1993); Chen et al. (1984); Zhu et al., Cancer letters (2011);

Jones et al., Br J Nutr (2012)

Table 2. Therapeutic Properties of Probiotics

There is a growing body of evidence that ingested beneficial bacteria, called probiotics, can beneficially modulate chronic intestinal inflammation, diarrhea, constipation, vaginitis, irritable bowel syndrome, atopic dermatis, food allergies and liver disease (Wallace et al., 2011, Nutrition reviews).

Probably the most promising area is the alleviation of symptoms linked to inflammatory bowel diseases (IBD), a growing health concern. As an example, the probiotic preparation VSL\#3 induced remission in children $(n=18)$ with mild to moderate ulcerative colitis (UC) (Huynh et al., 2009, Inflamm. Bowel Dis.) Accordingly, VSL\#3 was tested in a 1-year, placebo-controlled, double-blind clinical study on UC children $(n=29)$. Remission was achieved in $36.4 \%$ of children receiving IBD therapy and placebo, but in $92.8 \%$ of children receiving IBD therapy and VSL\#3 (Milele et al., 2009, Am J Gastroeterol.) Similar promising 
results were obtained with the probiotic Escherichia coli Nissle 1917 strain (Kruis et al., 2004, Gut ; Do et al., Ann Pharmacother, 2010). However, a review of available data indicates that more clinical studies are needed to confirm the beneficial effects of these products in UC and in inactive pouch patients (Jonkers et al., 2012, Drugs). This review also states that there is no evidence to support the use of probiotics in Crohn's disease.

Other studies confirm these findings. Miele et al. (2009) reported that all of 29 patients studied responded to inflammatory bowel disease therapy. Remission was achieved in $92.8 \%$ of patients treated with mixed probiotics and $36.4 \%$ of patients treated with placebo. Overall, $21.4 \%$ patients treated with a mix of probiotics and $73.3 \%$ patients treated with placebo relapsed within 1 year of follow-up.

Urinary tract infections (UTIs) are a common and frequently recurrent infection among women. Depletion of vaginal lactobacilli is associated with UTI risk, which suggests that repletion of the bacteria may be beneficial. Young women with a history of recurrent UTI were randomized to receive either a probiotic or placebo daily. Recurrent UTI occurred in $15 \%$ of women receiving probiotic compared with $27 \%$ of women receiving placebo (Stapleton et al., 2011).

Probiotics have considerable potential for preventive and therapeutic applications in gastrointestinal disorders. However, it is important to note that many probiotic health claims have not yet been substantiated through experimental evidence. In addition, the efficacy demonstrated for a single given bacterial strain cannot be extrapolated to other probiotic organisms. Moreover, the mechanisms underlying probiotic action have not yet been fully elucidated. A better understanding of these mechanisms will be able to shed light on the disparate clinical data and provide new tools to help the prevention or treatment of health disorders (Wohlgemuth et al., 2010; Yan et al., 2011).

\section{Application of probiotic bacteria in dairy foods}

There is evidence that food matrices play an important role in the beneficial health effects of probiotics on the host (Espirito Santo et al., 2011).

Fermented foods, particularly dairy foods, are commonly used as probiotic carriers. Fermented beverages provide an important contribution to the human diet in many countries because fermentation is an inexpensive technology which preserves food, improves its nutritional value and enhances its sensory properties (Gadaga et al., 1999). However, the increasing demand for new probiotic products has encouraged the development of other matrices to deliver probiotics, such as ice cream, infant milk power and fruit juice.

Davidson et al. (2000) evaluated the viability of probiotic strains in low-fat ice cream. They used cultures containing Streptococcus salivarius ssp. thermophilus and Lactobacillus delbrueckii ssp. Bulgaricus, Bifidobacterium longum and Lactobacillus acidophilus, and verified that culture bacteria did not decrease in the yogurt during frozen storage. Also, the presence of probiotic 
bacteria did not alter the sensory characteristics of the ice cream. The ice cream matrix may offer a good vehicle for probiotic cultures due to its composition, which includes milk proteins, fat and lactose, as well as other compounds. Moreover, its frozen state contributes to its efficiency. However, a probiotic ice cream product should have relatively high $\mathrm{pH}$ values -5.5 to 6.5 , in order to favor an increased survival of lactic cultures during storage. The lower acidity also results in increased consumer acceptance, especially among consumers who prefer milder Products. (Cruz et al., 2009b).

Growth of a probiotic yeast, Saccharomyces boulardii, in association with the bio-yogurt microflora, which is done by incorporating the yeast into commercial bio-yogurt, has been suggested as a way to stimulate growth of probiotic organisms and to assure their survival during storage. Lorens-Hattingh and Viljoen (2001a) studied the ability of probiotic yeast to grow and survive in dairy products, namely bio-yogurt, UHT yogurt and UHT milk. S. boulardii was incorporated into these dairy products and stored at $4{ }^{\circ} \mathrm{C}$ over a 4 -week period. It was observed that the probiotic yeast species, S. boulardii, had the ability to grow in bioyogurt and reach maximum counts exceeding $10^{7} \mathrm{CFU} \mathrm{g}{ }^{-1}$. The number of yeast populations was substantially higher in the fruit-based yogurt, mainly due to the presence of sucrose and fructose derived from the fruit. Despite the inability of $S$. boulardii to utilize lactose, the yeast species utilized available organic acids, galactose and glucose derived from bacterial metabolism of the milk sugar lactose present in the dairy products.

The viability of strains of L. acidophilus and Bifidobacterium animalis ssp. lactis in stirred yoghurts with fruit preparations of mango, mixed berry, passion fruit and strawberry was evaluated during shelf-life (Godward et al., 2000; Kailasapathy et al., 2008). The authors observed that regardless of concentrations, the addition of any of the fruit preparations had no effect on the counts of the two probiotics tested.

Fermented milks supplemented with lemon and orange fibers increased the counts of $L$. acidophilus and L. casei during cold storage compared to the control set. This was not the case for B. bifidum, possibly owing to the well-known sensitivity of bifidobacteria species to an acidic environment (Sendra et al., 2008).

\section{Probiotic cheeses}

Probiotic foods are currently primarily found in fermented milk drinks and yogurt, both of which have limited shelf life compared to cheeses. Incorporation of probiotic cultures in cheeses offers the potential not only to improve health but also product quality. It also opens the way to increasing the range of probiotic products on the market. The manufacture of most cheeses involves combining four ingredients: milk, rennet, microorganisms and salt These are processed using a number of common steps such as gel formation, whey expulsion, acid production and salt addition. Variations in ingredient blends and subsequent processing have led to the evolution of all cheese varieties.

Cheeses are dairy products which have a strong potential for delivering probiotic microorganisms into the human intestine, due to their specific chemical and physical 
characteristics. Cheeses have higher $\mathrm{pH}$ levels, lower titratable acidity, higher buffering capacity, more solid consistency, relatively higher fat content, higher nutrient availability and lower oxygen content than yogurts. These qualities protect probiotic bacteria during storage and passage through the gastrointestinal tract (Karimi et al., 2011; Ong et al., 2006).

As mentioned above, the physicochemical properties of food influence probiotic bacteria survival in the digestive tract, due to the low $\mathrm{pH}$ in the stomach, typically between 2.5 and 3.5 (Holzapfel et al., 1998), and the anti-microbial activity of pepsin that serve as effective barriers against the entrance of bacteria into the intestinal tract. Values of $\mathrm{pH}$ between 1 and 5 are commonly employed in determining the in vitro acid tolerance of Lactobacillus and Bifidobacterium spp. (Charteris et al., 1998). Bile salt concentrations between $0.15 \%$ and $0.3 \%$ have been recommended as appropriate for selection of probiotic bacteria for human consumption (Yang and Adams, 2004).

A variety of microorganisms, typically food-grade lactic acid bacteria (LAB), have been evaluated for their probiotic potential and have been applied as adjunct cultures in various food products or therapeutic preparations (Rodgers, 2008). Lactobacillus and Bifidobacterium species may be found in many foods; some are frequently regarded as probiotics due to their capacity to improve certain biological functions in the host. Complex interactions occur among resident microbiota, epithelial and immune cells and probiotics. These interactions play a major role in the development and maintenance of the beneficial activities for healthy humans (Medici el al., 2004).

According to Karimi et al. (2012), recommendations for the minimum viable counts of each probiotic strain in gram or millilitre of probiotic products vary when it comes to providing health benefits related to probiotic organisms. For example, the minimum viable levels of $10^{5} \mathrm{cfu} \mathrm{g}^{-1}$ have been recommended (Shah, 1995); while $10^{6} \mathrm{cfu} \mathrm{g}^{-1}$ (Karimi and Amiri-Rigi, 2010; Talwalkar and Kailasapathy, 2004) and $10^{7} \mathrm{cfu} \mathrm{g}^{-1}$ (Samona and Robinson, 1994) have been suggested for probiotics in different products. However, populations of $10^{6}-10^{7} \mathrm{CFU} / \mathrm{g}$ in the final product have been shown to be more acceptable as efficient levels of probiotic cultures in processed foods (Talwalkar, Miller, Kailasapathy and Nguyen, 2004), with numbers attaining $10^{8}-10^{9} \mathrm{CFU}$ when provided by a daily consumption of $100 \mathrm{~g}$ or $100 \mathrm{~mL}$ of probiotic food, and hence benefiting human health (Jayamanne \& Adams, 2006). It is important to emphasize that the incorporation of probiotic cultures into cheeses would produce functional foods only if the cultures remained viable in recommended numbers during maturation and shelf life of the products.

One of the preconditions for a bacterial strain to be called probiotic is the strain's ability to survive in the gastrointestinal environment, although the importance of viability for the beneficial effects of probiotics has not been well defined since inactivated and dead cells can also have immunological and health-promoting effects (Ghadimi et al., 2008; Lopez et al., 2008). Moreover, there are significant technological challenges associated with the introduction and maintenance of high numbers of probiotic microorganisms in foods that depend on the form of the probiotic inoculant, and with the viability and maintenance of 
probiotic characteristics in the food product up to the time of consumption. Spray drying has been used as a preservation method for microbial cultures. Gardiner et al. (2002) produced spray-dried probiotic milk powder containing the probiotic Lactobacillus paracasei NFBC 338. The powder contained $1 \times 10^{9} \mathrm{CFU}_{\mathrm{g}}{ }^{-1} \mathrm{~L}$. paracasei which was used as adjunct inoculums during probiotic Cheddar cheese manufacture. After three months of ripening, the count was $7.7 \times 10^{7} \mathrm{CFU} \cdot \mathrm{g}^{-1}$, without any adverse effects on the cheese. The researchers' data shows that probiotic spray-dried powder may be a useful means for adding probiotic strains to dairy products.

In order to use probiotic bacteria in the manufacture of cheese products, the process may have to be modified and adapted to the requirements of the strains employed. Overall, probiotic strains should be technologically compatible with the food manufacturing process involved. With regard to the development of probiotic cheeses, this means that such strains should be cultivable to high cell density for inoculation into the cheese vat, or that the strains are capable of proliferating during the manufacturing and/or ripening process (Ross et al., 2002). In general, a probiotic cheese should have the same attributes as a conventional cheese: the incorporation of probiotic bacteria should not imply a loss of quality of the product. In this context, the level of proteolysis and lipolysis must be the same or even better than for cheese which does not have functional food appeal (Cruz et al., 2009a).

Proteolysis plays a critical role in determining typical sensory characteristics and represents a significant quality indicator for certain cheeses. Proteolysis is caused by enzymes found in milk (plasmin), rennet (pepsin and chymosin) and microbial enzymes released by starter cultures. The activities of these enzymes hydrolyze the fractions of caseins, which leads to the formation of peptides. These peptides may be further hydrolyzed with proteolytic enzymes originating from microbiota such as starter bacteria, non-starter lactic acid bacteria (NSLAB) and probiotic adjuncts to the cheeses, into smaller peptides and free amino acids, which are important for flavor development in some cheeses (Ong et al., 2007; Cliffe et al., 1993; Lynch et al., 1999).

Three batches of Cheddar cheeses (Batch 1, with only starter lactococci; Batch 2, with lactococci and Lactobacillus acidophilus 4962, Lb. casei 279, Bifidobacterium longum 1941; Batch 3, with lactococci and Lb. acidophilus LAFTIs L10, Lb. paracasei LAFTI L26, B. lactis LAFTI B94) were manufactured in triplicate to study the survival and influence of probiotic bacteria on proteolytic patterns and production of organic acid during a ripening period of 6 months at $4{ }^{\circ} \mathrm{C}$. All probiotic adjuncts survived the manufacturing process and maintained their viability of $7.5 \log 10 \mathrm{cfu} \mathrm{g}^{-1}$ at the end of the ripening term. The number of lactococci decreased by one to two log cycles, but their counts were not significantly different $(P>$ 0.05) in either the control or the probiotic cheeses. No significant differences were observed in composition (fat, protein, moisture, salt content), although acetic acid concentration was higher in the probiotic cheeses. Proteolysis assessment during ripening showed no significant differences $(\mathrm{P}>0.05)$ in the level of water-soluble nitrogen (primary proteolysis), but the levels of secondary proteolysis indicated by the concentration of free 
amino acids were significantly higher $(\mathrm{P}>0.05)$ in probiotic cheeses. These data thus suggested that Cheddar cheese is an effective vehicle for the delivery of probiotic organisms (Ong et al., 2006).

Phillips et al. (2006) have also studied probiotic Cheddar cheese. They manufactured six batches of Cheddar cheese containing different combinations of commercially-available probiotic cultures. Duplicate cheeses contained organisms from each supplier, Bifidobacterium spp., Lactobacillus acidophilus and either Lactobacillus casei, Lactobacillus paracasei, or Lactobacillus rhamnosus. Using selective media, the different strains were assessed for viability during Cheddar cheese maturation over 32 weeks. Bifidobacterium sp. remained at high numbers with the three strains present in cheese at $4 \times 10^{7}, 1.4 \times 10^{8}$, and $5 \times 10^{8} \mathrm{CFU} / \mathrm{g}$ respectively after 32 weeks. Similarly, the L. casei $\left(2 \times 10^{7} \mathrm{CFU} / \mathrm{g}\right)$, L. paracasei $\left(1.6 \times 10^{7} \mathrm{CFU} / \mathrm{g}\right)$, and L. rhamnosus $\left(9 \times 10^{8} \mathrm{CFU} / \mathrm{g}\right)$ strains survived well. However, the $L$. acidophilus strains performed poorly. Both decreased in a similar manner and were recorded at $3.6 \times 10^{3} \mathrm{CFU} / \mathrm{g}$ and $4.9 \times 10^{3} \mathrm{CFU} / \mathrm{g}$ after 32 weeks.

Numerous scientific papers have been published on the development of fresh cheeses containing recognized and potentially probiotic cultures. They have described suitable viable counts as well as a positive influence on texture and sensorial properties of the cheeses. Cottage cheese in particular shows an adequate profile for the incorporation of probiotic cells and/or prebiotic substances. In addition, cottage cheese is a healthy alternative to many other cheeses by virtue of its low fat content.

Araújo et al. (2010) developed a symbiotic cottage cheese containing Lactobacillus delbrueckii UFV H2b20 and inulin, and evaluated the survival of this bacterium when the cheese was exposed to conditions simulating those found in the gastro-intestinal tract. Throughout the entire storage period of the cheese, the probiotic cell counts were higher than recommended levels for probiotic products. The probiotic bacterium exhibited satisfactory resistance to low $\mathrm{pH}$ values and to high concentrations of bile salts. The addition of probiotic cells and inulin generated no alterations in the physicochemical characteristics of cheese. By allowing the viable microorganism has characteristics desirable for incorporation of a probiotic strain. Probiotic cells could be added to the dressing, creamy liquid that surrounds the granules of cheese because after this step there is not exposition at high temperature.

Although cottage cheese is well adapted to the health requirements of modern populations, its consumption has been in decline over the past few years. By developing new production processes, cottage cheese, apart from carrying the nutritional qualities of milk, may also furnish consumers with a source of lactic acid bacteria, probiotic microorganisms and prebiotics. The lactic acid bacteria perform more critical functions in cottage cheese than just producing lactic acid. They also aid the manufacture process and increase the final rheological and sensorial qualities of the cheese. Controlling of the fermentation process with lactic acid bacteria allows for the enhancement of the sensorial quality of the cheese and could hence play a crucial role in increasing consumption of cottage cheese. 
Souza, et al. (2008) and Souza and Saad (2009) studied the manufacture of Minas fresh cheese supplemented solely with the probiotic strain of L. acidophilus La-5. Cheeses manufactured solely with La-5 presented populations above $1 \times 10^{6} \mathrm{CFU} / \mathrm{g}$, reaching $1 \times 10^{7}$ $\mathrm{CFU} / \mathrm{g}$ on the 14 th day of storage.

The Argentinean fresh cheese is a soft rindless cheese with a ripening period of 12 days at $5{ }^{\circ} \mathrm{C}$ before its commercial distribution. This cheese presents the following physicochemical characteristics: $\mathrm{pH} 5.29$, moisture $58 \%(\mathrm{w} / \mathrm{w})$, fat $12 \%(\mathrm{w} / \mathrm{w})$, proteins $23 \%(\mathrm{w} / \mathrm{w})$, salt $0.9 \%$ $(\mathrm{w} / \mathrm{w})$, ashes $3.4 \%(\mathrm{w} / \mathrm{w})$, dry matter $40.8 \%(\mathrm{w} / \mathrm{w})$ and calcium $0.6 \%(\mathrm{w} / \mathrm{w})$. This product has proven to be an adequate vehicle for probiotic bacteria during storage and until consumption. It offers offer a certain degree of protection of the viability of bacteria during the in vitro simulation of gastric transit (Vinderola et al., 2000).

Kasimoglu et al. (2004) have shown that L. acidophilus strain can be used for the manufacture of probiotic Turkish white cheese. The final numbers of L. acidophilus were greater than the minimum $\left(10^{7} \mathrm{cfu} \mathrm{g}^{-1}\right)$ required to make health benefits claims. Furthermore, L. acidophilus can be used to enhance flavor, texture, and a produce a high level of proteolysis. Moreover, probiotic cheese which was vacuum packed following salting was shown to be more acceptable than the corresponding cheese stored in brine following salting. Therefore, vacuum packaging is the preferred means for storing probiotic Turkish white cheeses.

\section{Concluding remarks and future trends}

In conclusion, probiotic microorganisms, including bacteria and yeasts, are attracting a growing interest due to their promising physiological effects as well as the value they add to probiotic-containing food products. There is a growing body of evidence that probiotics may play a beneficial role in human health (Ouwehand et al., 2002; Collado et al., 2009). Established effects in humans include alleviation of symptoms linked to lactose intolerance or to irritable bowel syndrome. They also include reduced diarrhea associated with antibiotic treatment, rotavirus or traveler's diseases. It should be emphasized that the beneficial properties of probiotic microorganisms are highly dependent on the strains, which means that each strain or product requires demonstration of the specific effects in vivo. The possibility of using certain probiotics to modulate the immune system, particularly at the mucosal level (O'Flaherty et al., 2010) is the most promising application. In this respect, promising healing effects were obtained using the probiotic mixture VSL\#3 on ulcerative colitis patients (Miele et al., 2009; Huynh et al., 2009; Ng et al., 2010). These clinical studies, which still need to be confirmed by larger studies, strongly suggest that selected strains of probiotics may help in treating the bowel diseases which constitute a growing health concern in developing countries. Clearly, animal studies suggest other promising probiotic effects incuding inflammatory diseases, allergies and associated asthma, and colorectal cancer. These applications open exciting avenues that must be investigated at both molecular and clinical levels.

Understanding the impact of ingested bacteria on health, as well as the impact of gut microbiota perturbation (dysbiosis) on emerging diseases, including immune disorders and 
cancer remains a great challenge. In developed countries, gut microbiota have evolved with a reduced diversity of bacterial species (Yatsunenko et al., 2012). This is particularly true in Crohn's disease patients (Manichanh et al., 2006), who lack immunomodulatory antiinflammatory bacteria, including Faecalibacterium prausnitzii (Sokol et al., 2008). A similar reduced diversity was also described in the case of colorectal cancer, (Chen et al., 2012) confirming the involvement of dysbiosis in digestive cancers (Azcarate-Peril et al., 2011). The composition of gut microbiota is linked to long term dietary patterns (Wu et al., 2011). This suggests that ingested bacteria can participate in the prevention and/or treatment of emerging diseases. This hypothesis has been reinforced by recent epidemiological studies which show that raw milk prevents the onset of allergy and asthma in children (Loss et al., 2011; Waser et al., 2007; Braun-Fahrlander et al., 2011). The authors suggested a protective immunomodulatory role of raw milk bacteria (Braun-Fahrlander et al., 2011).

Most interestingly, bacterial species used as dairy starters display promising properties in this field. For example, immunomodulatory anti-inflammatory properties were described in certain strains of Propionibacterium freudenreichii (Foligné et al., 2010; Deutsch et al., 2012), Streptococcus thermophilus (Ogita et al., 2011), Lactobacillus delbrueckii subsp. bulgaricus and subsp. lactis (Santos-Rocha et al., 2012), as well as Lactobacillus helveticus (Guglielmetti et al., 2010). Modulation of colon cancer cell growth was also reported in vitro and/or in animal models for P. freudenreichii (Cousin et al., 2010; Lan et al., 2008), when the cells were exposed to yogurt containing S. thermophilus and L. bulgaricus (Narushima et al., 2010; Perdigon et al., 2002) and L. helveticus (de Moreno et al., 2010). Future trends may thus include the development of specific fermented dairy products designed for specific population. These could use bacteria strains and employ both technological capabilities and probiotic potential to affect immune system modulation, gut physiology and cancer cells.

\section{Author details}

Emiliane Andrade Araújo

Universidade Federal de Viçosa, Campus Rio Paranaíba, Rio Paranaíba, MG, Brazil

Ana Clarissa dos Santos Pires and Antônio Fernandes de Carvalho*

Departamento de Tecnologia de Alimentos, Universidade Federal de Viçosa, Viçosa, MG, Brazil

Maximiliano Soares Pinto

Instituto de Ciências Agrárias, Universidade Federal de Minas Gerais, Montes Claros, MG, Brazil

Gwénaël Jan

INRA, UMR1253 Science et Technologie du Lait et de l'CEuf, Rennes, France

\section{Acknowledgement}

We would like to thank to Mary Margaret Chappell for reading and contributing. The authors are supported by grants from the FAPEMIG, CAPES and CNPq.

${ }^{*}$ Corresponding Author 


\section{References}

Araujo, E. A., Carvalho, A. F., Leandro, E. S., Furtado, M.M., Moraes, C. A. (2010). Development of a symbiotic cottage cheese added with Lactobacillus delbrueckii UFV H2b20 and inulin. Journal of Functional Foods, 2, 85-89.

Azcarate-Peril, M. A., Sikes, M., Bruno-Barcena, J. M. (2011). The intestinal microbiota, gastrointestinal environment and colorectal cancer: a putative role for probiotics in prevention of colorectal cancer? Am. J. Physiol Gastrointest. Liver Physiol,, 301:G401-G424.

Benton, D., Williams, C., Brown, A. (2007). Impact of consuming a milk drink containing a probiotic on mood and cognition. European Journal of Clinical Nutrition, 61, 355-361.

Braun-Fahrlander, C., \& Von, M. E. (2011). Can farm milk consumption prevent allergic diseases? Clin. Exp. Allergy, 41:29-35.

Charteris, W. P., Kelly, P. M., Morelli, L., Collins, J. K. (1998). Development and application of in vitro methodology to determine the transit tolerance of potentially probiotic Lactobacillus and Bifidobacterium species in the upper human gastrointestinal tract. Journal of Applied Microbiology, 84, 759-768.

Chen, W. J. L., Anderson, J. W., Jennings, D. (1984). Propionate may mediate the hypocholesterolemic effects of certain soluble plant fibers in cholesterol-fed rats. Proc. Soc. Exp. Biol. Med,175, 215-218.

Chen, W., Liu, F., Ling, Z., Tong, X., Xiang, C. (2012). Human intestinal lumen and mucosaassociated microbiota in patients with colorectal cancer. PLoS. ONE., 7:e39743.

Clancy, R. (2003) Immunobiotics and the probiotic evolution. FEMS Immunology and Medical Microbiology, 38, 9-12.

Cliffe, A. J., Marks, J. D.; Mulholland, F. (1993). Isolation and characterization of non-volatile flavors from cheese: Peptide profile of flavor fractions from Cheddar cheese, determined by reverse-phase high performance liquid chromatography. International Dairy Journal, 3, 379-387.

Collado, M. C., Isolauri, E., Salminen, S., Sanz, Y. (2009). The impact of probiotic on gut health. Curr. Drug Metab, 10:68-78.

Costello, E. K., Lauber, C. L., Hamady, M., Fierer, N., Gordon, J. I., Knight, R. (2009) Bacterial community variation in human body habitats across space and time. Science, 326, 1694-1697.

Cousin, F. J., Jouan-Lanhouet, S., Dimanche-Boitrel, M. T., Corcos, L., Jan, G. (2012). Milk Fermented by Propionibacterium freudenreichii Induces Apoptosis of HGT-1 Human Gastric Cancer Cells. PLoS. ONE., 7:e31892.

Crittenden, R. G. Prebiotics. In: Tannock, G. W. (Ed.). (1999). Probiotics: a critical review. Norfolk: Horizon Scientific Press, 141-156.

Cruz, A. G., Buriti, F. C. A., Souza, C. H. B., Faria, J. A. F., Saad, S. M. I. (2009a). Probiotic cheese: health benefits, technological and stability aspects. Trends in Food Science $\mathcal{E}$ Technology, 20, 344-354.

Cruz, A.G., Antunes, A.E.C., Sousa, A.L.O.P., Faria, J.A.F., Saad, S.M.I. (2009b). Ice-cream as a probiotic food Carrier. Food Research International, 42, 1233-1239. 
Cruz, A.G., Faria, J.A.F., Van Dender, A.G.F. (2007). Packaging system and probiotic dairy foods. Food Research International, 40, 951-956.

Davidson, R.H., Duncan, S.E., Hackney, C.R., Eigel, W.N., Boling, J.W. (2000). Probiotic Culture Survival and Implications in Fermented Frozen Yogurt Characteristics. Journal of Dairy Science, 83, 666-673.

de Moreno, L. A., \& Perdigon, G. (2010). The application of probiotic fermented milks in cancer and intestinal inflammation. Proc. Nutr. Soc., 69:421-428.

Deutsch, S. M., Parayre, S., Bouchoux, A., Guyomarc'h, F., Dewulf, J., Dols-Lafargue, M., Baglinière, F., Cousin, F. J., Falentin, H., Jan, G., Foligné, B. (2012). Contribution of surface beta-glucan polysaccharide to physicochemical and immunomodulatory properties of Propionibacterium freudenreichii. Appl. Environ. Microbiol., 78:1765-1775.

Espirito Santo, A.P., Perego, P., Converti, A., Oliveira, M.N. (2011). Influence of food matrices on probiotic viability: A review focusing on the fruity bases. Trends in Food Science \& Technology, 22, 377-385.

Foligné, B., Deutsch, S. M., Breton, J., Cousin, F. J., Dewulf, J., Samson, M., Pot, B., Jan, G. (2010). Promising immunomodulatory effects of selected strains of dairy propionibacteria as evidenced in vitro and in vivo. Appl. Environ. Microbiol., 76:8259-8264.

Fuller, R. (1989). Probiotics in man and animals. Journal of Applied Bacteriology, 66, 365-378.

Gadaga, T. H., Mutukumira, A. N., Narvhus, J. A., Feresu, S. B. (1999). A review of traditional fermented foods and beverages of Zimbabwe. International Journal of Food Microbiology, 53, 1-11.

Gardiner, G. E., Bouchier, P., O’sullivan, E., Kelly, J., Collins, K., Fitzgerald, G., Ross, R.P., Stanton, C. (2002). A spray-dried culture for porbiotic Cheddar chesse manufacture. International Dairy Journal, 12, 749-756.

Ghadimi, D., Folster-Holst, R., De Vrese, M., Winkler, P., Heller, K.J., Schrezenmeir, J. (2008). Effects of probiotic bacteria and their genomic DNA on TH1/TH2-cytokine production by peripheral blood mononuclear cells (PBMCs) of healthy and allergic subjects. Immunobiology, 213, 677-692.

Gibson, G. R., Fuller, R. (2000) Aspects of in vitro and in vivo research approaches directed toward identifying probiotics and prebiotics for human use. Journal Nutrition, 130, 391395.

Godward, G., Sultana, K., Kailasapathy, K., Peiris, P., Arumugaswamy, R., \& Reynolds, N. (2000). The importance of strain selection on the viability and survival of probiotic bacteria in dairy foods. Milchwissenschaft, 55, 441-445.

Guglielmetti, S., Taverniti, V., Minuzzo, M., Arioli, S., Zanoni, I., Stuknyte, M., Granucci, F., Karp, M., Mora, D. (2010). A dairy bacterium displays in vitro probiotic properties for the pharyngeal mucosa by antagonizing group A streptococci and modulating the immune response. Infect. Immun., 78:4734-4743.

Holzapfel, W. H., Haberer, P., Snel, J., Schillinger, U., \& Huis In't Velt, J. H. J. (1998). Overview of gut flora and probiotics. International Journal of Food Microbiology, 41, 85101. 
Huynh, H. Q., Debruyn, J., Guan, L., Diaz, H., Li, M., Girgis, S., Turner, J., Fedorak, R., Madsen, K. (2009). Probiotic preparation VSL\#3 induces remission in children with mild to moderate acute ulcerative colitis: a pilot study. Inflamm. Bowel. Dis., 15:760-768.

Hyun, C., Shin, H. (1998). Utilization of bovine plasma obtained from a slaughterhouse for economic production of probiotics. Journal of Fermentation and Bioenginering, 86, 34-37.

Jayamanne, V. S., \& Adams, M. R. (2006). Determination of survival, identity, and stress resistance of probiotic bifidobacteria in bio-yoghurts. Letters in Applied Microbiology, 42(3),189-194.

Kailasapathy, K., Harmstorf, I., \& Phillips, M. (2008). Survival of Lactobacillus acidophilus and Bifidobacterium animalis ssp lactis in stirred fruit yogurts. LWT-Food Science and Technology, 41, 1317-1322.

Karimi, R., Amiri-Rigi, A., 2010. Probiotics in Dairy Products. Marz Danesh Publication, Tehran.

Karimi, R., Mortazavian, A.M., Amiri-Rigi, A. (2012). Selective enumeration of probiotic microorganisms in cheese. Food Microbiology, 29,1-9.

Karimi, R., Mortazavian, A.M., Da Cruz, A.G. (2011). Viability of probiotic microorganisms in cheese during production and storage: a review. Dairy Science and Technology, 91, 283308.

Kasimoglu, A., Goncuoglu, M., Akgun, S. (2004). Probiotic White cheese with Lactobacillus acidophilus. International Dairy Journal, 14, 1067-1073.

Lan, A., Bruneau, A., Bensaada, M., Philippe, C., Bellaud, P., Rabot, S., Jan, G. (2008). Increased induction of apoptosis by Propionibacterium freudenreichii TL133 in colonic mucosal crypts of human microbiota-associated rats treated with 1,2dimethylhydrazine. Br. J Nutr., 100:1251-1259.

Lopez, M., Li, N., Kataria, J., Russell, M., Neu, J. (2008). Live and ultraviolet-inactivated Lactobacillus rhamnosus GG decrease flagellin-induced interleukin-8 production in Caco2 cells. Journal of Nutrition, 138, 2264-2268.

Loss, G., Apprich, S., Waser, M., Kneifel, W., Genuneit, J., Buchele, G., Weber, J., Sozanska, B., Danielewicz, H., Horak, E., Van Neerven, R. J., Heederik, D., Lorenzen, P. C., Von, M. E., Braun-Fahrlander, C. (2011). The protective effect of farm milk consumption on childhood asthma and atopy: the Gabriela study. J. Allergy Clin. Immunol., 128:766-773.

Lourens-Hattingh,A., Viljoen, B.C. (2001a). Growth and survival of a probiotic yeast in dairy products. Food Research International, 34, 791-796.

Lourens-Hattingh,A., Viljoen, B.C. (2001b). Yogurt as probiotic carrier food. International Dairy Journal, 11, 1-17.

Lynch, C. M., Muir, D. D., Banks, J. M., Mcsweeney, P. L. H.; Fox, P. F. (1999). Influence of adjunct cultures of Lactobacillus paracasei ssp. paracasei or Lactobacillus plantarum on Cheddar cheese ripening. Journal of Dairy Science, 82, 1618-1628.

Macfarlane, G. T. Gibson, G. R. Cummings, J. H. (1992) Comparison of fermentation reactions in different regions of the human colon. Journal Applied Bacteriology, 72(3), 5764 . 
Manichanh, C., Rigottier-Gois, L., Bonnaud, E., Gloux, K., Pelletier, E., Frangeul, L., Nalin, R., Jarrin, C., Chardon, P., Marteau, P., Roca, J., Dore, J. (2006). Reduced diversity of faecal microbiota in Crohn's disease revealed by a metagenomic approach. Gut, 55:205211.

Margoles, A., Garcia, L. (2003). Characterisation of a bifidobacterium strain wish acquired resistance to cholate: A preliminary study. International Journal of Food Microbiology, 80, 191-198.

Medici, M., Vinderola, C. G., Perdigon, G. (2004). Gut mucosal immunomodulation by probiotic fresh chesse. International Dairy Journal, 14, 611-618.

Miele, E., Pascarella, F., Giannetti , E., Quaglietta , L Robert N. Baldassano , R. N., Annamaria Staiano, A. (2009). Effect of a Probiotic Preparation (VSL\#3) on Induction and Maintenance of Remission in Children With Ulcerative Colitis. American Journal of Gastroenterology, 104, 437-443.

Miele, E., Pascarella, F., Giannetti, E., Quaglietta, L., Baldassano, R. N., Staiano, A. (2009). Effect of a probiotic preparation (VSL\#3) on induction and maintenance of remission in children with ulcerative colitis. Am. J. Gastroenterol., 104:437-443.

Moura, M.R. L., (2005). Alimentos Funcionais: seus benefícios e a legislação: Avaiable in: http://acd.ufrj.br/consumo/leituras/ld.htm\#leituras.

Narushima, S., Sakata, T., Hioki, K., Itoh, T., Nomura, T., Itoh, K. (2010). Inhibitory effect of yogurt on aberrant crypt foci formation in the rat colon and colorectal tumorigenesis in RasH2 mice. Exp. Anim., 59:487-494.

Ng, S. C., Plamondon, S., Kamm, M. A., Hart, A. L., Al-Hassi, H. O., Guenther, T., Stagg, A. J., Knight, S. C. (2010). Immunosuppressive effects via human intestinal dendritic cells of probiotic bacteria and steroids in the treatment of acute ulcerative colitis. Inflamm. Bowel. Dis., 16:1286-1298.

O'flaherty, S., Saulnier, D. M., Pot, B., Versalovic, J. (2010). How can probiotics and prebiotics impact mucosal immunity? Gut Microbes, 1:293-300.

Ogita, T., Nakashima, M., Morita, H., Saito, Y., Suzuki, T., Tanabe, S. (2011). Streptococcus thermophilus ST28 ameliorates colitis in mice partially by suppression of inflammatory Th17 cells. J. Biomed. Biotechnol., 2011:378417.

Ong, L., Henriksson, A., Shah, N.P. (2006) Development of probiotic Cheddar cheese containing Lactobacillus acidophilus, Lb. casei, Lb. paracasei and Bifidobacterium spp. and the influence of these bacteria on proteolytic patterns and production of organic acid. International Dairy Journal 16, 446-456.

Ong, L., Henrikssonb, A., Shaha, N. P. Chemical analysis and sensory evaluation of Cheddar cheese produced with Lactobacillus acidophilus, Lb. casei, Lb. paracasei or Bifidobacterium sp. International Dairy Journal 17 (2007) 937-945.

Ouwehand, A. C., Salminen, S., Isolauri, E. (2002). Probiotics: an overview of beneficial effects. Anton. Leeuw. Int. J. G., 82:279-289.

Perdigon, G., De Moreno, D. L., Valdez, J., Rachid, M. (2002). Role of yoghurt in the prevention of colon cancer. Eur. J. Clin. Nutr., 56 Suppl 3:S65-S68. 
Prado, F.C., Parada, J.L., Pandey, A., Soccol, C.R. (2008). Trends in non-dairy probiotic beverages. Food Research International, 41, 111-123.

Rastall, R. A., Fuller, R., Gaskins H. R., Gibson G. R. (2000) Colonic functional foods. In Functional Foods, 71-89 [GR Gibson and CM Williams, editors]. Cambridge: Woodhead Publishing Limited.

Reddy, B. S., Rivenson, A. (1983) Inhibitory effect of Bifidobacterium longum on colon, mammary, and liver carcinogenesis induced by 2-amino-3-methyllimidazo [4,5f]quinoline, a food mutagen. Cancer Research, 53, 3914-3918.

Reid G., Jessica A., Younes, J. A., Van Der Mei, H. C., Gloor, G. B., Knight, R., Busscher, H. J. (2011) Gut flora restoration: natural and supplemented recovery of human microbial communities. Nature Reviews. 9, 27-38.

Rodgers, S. (2008). Novel applications of live bacteria in food services: probiotics and protective cultures. Trends Food Sci. Tech. 19, 188-197.

Ross, R. P., Fitzgerald, G., Collins, K., Stanton, C. (2002). Cheese delivering biocultures: probiotic cheese. Australian Journal of Dairy Technology, 57(2), 71-78.

Saarela, M., Mogensen, G., Fonden, R., Matto, J., Mattila-Sandholm, T. (2000). Probiotic bacteria: safety, functional and technological properties. Journal of Biotechnology, 84, 197215.

Samona, A., Robinson, R.K. (1994). Effect of yogurt cultures on the survival of bifidobacteria in fermented milks. Journal of the Society of Dairy Technology 47, 58-60.

Santos-Rocha C., Lakhdari, O., Blottiere, H. M., Blugeon, S., Sokol, H., Bermu'dez-Humara'n, L. G., Azevedo, V., Miyoshi, A., Dore, J., Langella, P., Maguin, E., Van De, G. M. (2012). Anti-inflammatory properties of dairy lactobacilli. Inflamm. Bowel. Dis., 18:657-666.

Sendra, E., Fayos, P., Lario, Y., Fernandez-Lopez, J., Sayas-Barbera, E., \& Perez-Alvarez, J. (2008). Incorporation of citrus fibers in fermented milk containing probiotic bacteria. Food Microbiology, 25, 13-21.

Shah, N.P., Lankaputhra, W.E.V., Britz, M.L., Kyle, W.S.A. (1995). Survival of Lactobacillus acidophilus and Bifidobacterium bifidum in commercial yoghurt during refrigerated storage. International Dairy Journal, 5, 515-521.

Sokol, H., Pigneur, B., Watterlot, L., Lakhdari, O., Bermudez-Humaran, L. G., Gratadoux, J. J., Blugeon, S., Bridonneau, C., Furet, J. P., Corthier, G., Grangette, C., Vasquez, N., Pochart, P., Trugnan, G., Thomas, G., Blottiere, H. M., Dore, J., Marteau, P., Seksik, P., Langella, P. (2008). Faecalibacterium prausnitzii is an anti-inflammatory commensal bacterium identified by gut microbiota analysis of Crohn disease patients. Proc. Natl. Acad. Sci. U. S. A, 105:16731-16736.

Souza, C. H. B., \& Saad, S. M. I. (2009). Viability of Lactobacillus acidophilus La-5 added solely or in co-culture with a yoghurt starter culture and implications on physicochemical and related properties of Minas fresh cheese during storage. LWT e Food Science and Technology, 42(2), 633-640.

Souza, C. H. B., Buriti, F. C. A., Behrens, J. H., \& Saad, S. M. I. (2008). Sensory evaluation of probiotic Minas fresh cheese with Lactobacillus acidophilus added solely or in co-culture 
with a thermophilic starter culture. International Journal of Food Science and Technology, 43(5), 871-877.

Stapleton, A. E., Au-Yeung, M., Hooton, T. M., Fredricks, D. N., Roberts, P. L., Czaja, C. A., Yarova-Yarovaya, Y., Fiedler, T., Cox, M., Stamm, W. E. (2011). Randomized, Placebocontrolled Phase 2 Trial of a Lactobacillus crispatus Probiotic Given Intravaginally for Prevention of Recurrent Urinary Tract Infection. Clinical Infectious Diseases, 52 (10), 12121217.

Talwalkar, A., Kailasapathy, K. (2004). Comparison of selective and differential media for the accurate enumeration of strains of Lactobacillus acidophilus, Bifidobacterium spp. and Lactobacillus casei complex from commercial yoghurts. International Dairy Journal, 14, 142-149.

Talwalkar, A., Miller, C. W., Kailasapathy, K., \& Nguyen, M. H. (2004). Effect of packaging materials and dissolved oxygen on the survival of probiotic bacteria in yoghurt. International Journal of Food Science and Technology, 39(6), 605-611.

Thamer, K. G.; Penna, A. L. B. (2005). Efeito do teor de soro, acucar e de frutooligossacarideos sobre a populacao de bacterias lacticas probioticas em bebidas fermentadas. Revista Brasileira de Ciências Farmacêuticas, 41(3), 393-400.

Topping, D. L. Clifton, P. M. (2001) SHorty-chain fatty acids and human colonic function: roles of resistant starch and nonstarch polysaccharides. Physiological Reviews, 81(3), 1031-1064.

Vinderola, C. G., Prosello, W., Ghiberto, D., Reinheimer, J. (2000). Viability of probiotic (Bifidobacterium, Lactobacillus acidophilus and Lactobacillus casei) and nonprobiotic microflora in argentinian Fresh cheese. Journal of Dairy Science, 83, 1905-1911.

Waser, M., Michels, K. B., Bieli, C., Floistrup, H., Pershagen, G., Von, M. E., Ege, M., Riedler, J., Schram-Bijkerk, D., Brunekreef, B., Van, H. M., Lauener, R., Braun-Fahrlander, C. (2007). Inverse association of farm milk consumption with asthma and allergy in rural and suburban populations across Europe. Clin. Exp. Allergy, 37:661-670.

Wohlgemuth, S., Gunnar Loh, G., Blaut, M. (2010). Recent developments and perspectives in the investigation of probiotic effects. International Journal of Medical Microbiology, 300, 310

Wu, G. D., Chen, J., Hoffmann, C., Bittinger, K., Chen, Y. Y., Keilbaugh, S. A., Bewtra, M., Knights, D., Walters, W. A., Knight, R., Sinha, R., Gilroy, E., Gupta, K., Baldassano, R., Nessel, L., Li, H., Bushman, F. D., Lewis, J. D. (2011). Linking long-term dietary patterns with gut microbial enterotypes. Science, 334:105-108.

Yan, F., Cao, H., Cover, T, L., Washington, M. K., Shi, Y, Liu, L., Chaturvedi, R., Peek Jr, R. M., Wilson, K. T., Polk, D. B. (2011). Colon-specific delivery of a probiotic-derived soluble protein ameliorates intestinal inflammation in mice through an EGFRdependent mechanism. Journal of Clinical Investigation, 121(6), 2242-2253.

Yang, H., \& Adams, M. C. (2004). In vitro assessment of the upper gastrointestinal tolerance of potential probiotic dairy propionibacteria. International Journal of Food Microbiology, 91, 253-260. 
Yatsunenko, T., Rey, F. E., Manary, M. J., Trehan, I., Dominguez-Bello, M. G., Contreras, M., Magris, M., Hidalgo, G., Baldassano, R. N., Anokhin, A. P., Heath, A. C., Warner, B., Reeder, J., Kuczynski, J., Caporaso, J. G., Lozupone, C. A., Lauber, C., Clemente, J. C., Knights, D., Knight, R., Gordon, J. I. (2012). Human gut microbiome viewed across age and geography. Nature, 486:222-227.
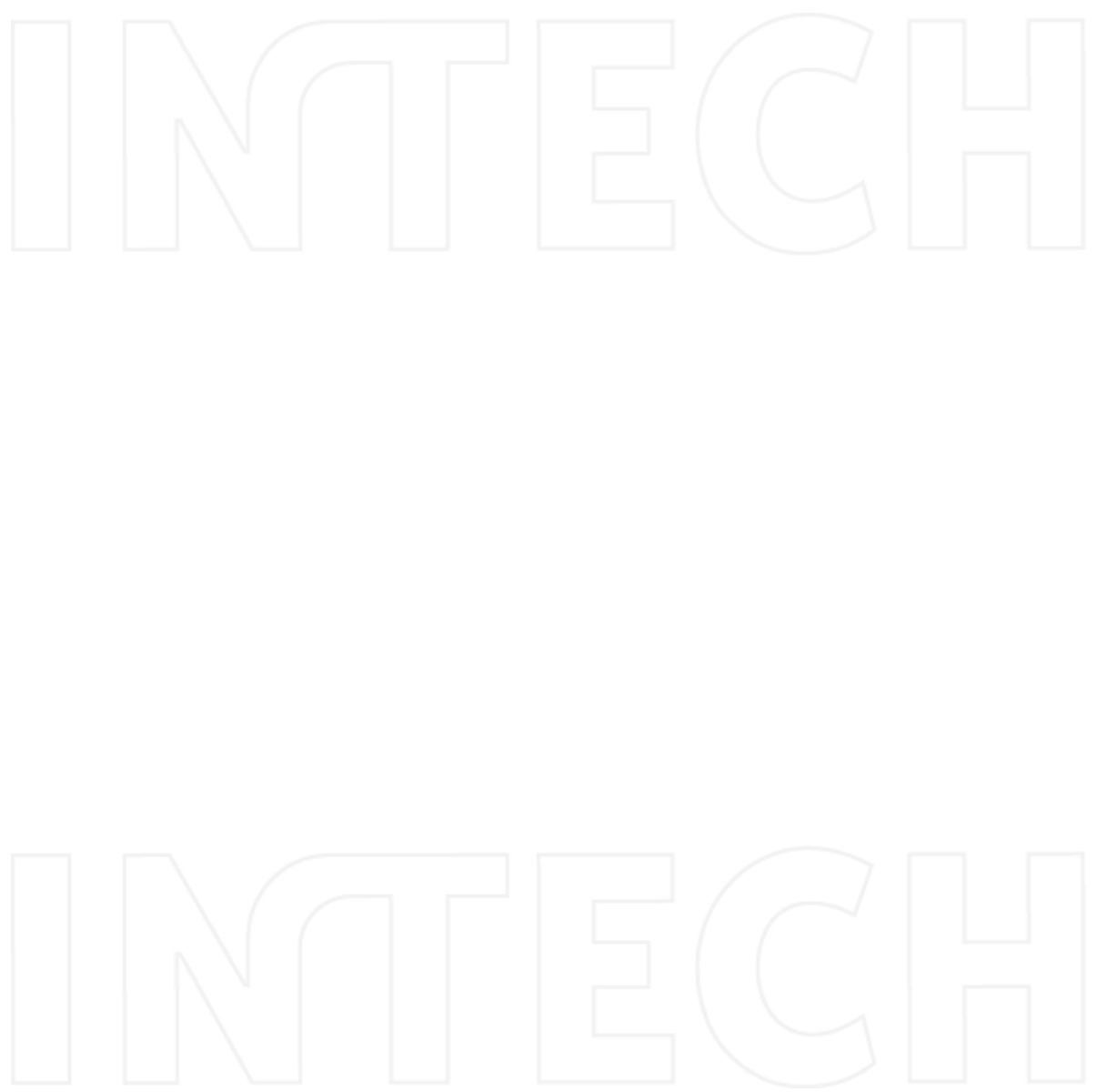